\title{
PERMASALAHAN HASIL PERTANGGALAN RADIOKARBON PADA SITUS PATIH MUHUR DAN POSISINYA DALAM SEJARAH KERAJAAN-KERAJAAN DI KALIMANTAN SELATAN
}

\section{THE PROBLEM OF PATIH MUHUR'S CARBON DATING AND ITS POSITION IN THE HISTORICAL KINGDOMS OF SOUTH KALIMANTAN}

\author{
Wasita \\ Balai Arkeologi Banjarmasin, Jalan Gotong Royong II, RT 03/06, Banjarbaru 70711, Kalimantan Selatan; \\ email:wasita6@yahoo.com
}

Diterima 6 Juni 2014

Direvisi 27 Maret 2015

Disetujui 10April 2015

\begin{abstract}
Abstrak. Kadang-kadang hasil analisis pertanggalan absolut, tidak sepenuhnya menuntaskan persoalan kronologi situs. Tidak jarang hasil pertanggalan absolut justru menimbulkan persoalan baru, contohnya di situs Patih Muhur. Berkaitan dengan itu, tujuan kajian ini dimaksudkan untuk memberikan sumbangan pemikiran mengenai penempatan situs Patih Muhur dalam kerangka sejarah kerajaan-kerajaan di Kalimantan Selatan. Metode yang digunakan adalah deskriptif-analitik. Aplikasinya dilakukan dengan mendeskripsikan tahapan pengambilan sampel, analisis yang dilakukan, dan membandingkan hasil pertanggalan absolut dan relatif. Kajian yang dilakukan menghasilkan temuan bahwa terdapat ketidaksinkronan antara pertanggalan absolut dan relatif. Berdasarkan temuan tersebut disimpulkan bahwa validitas hasil pertanggalan absolut tidak cukup dilakukan hanya dalam satu kali uji pertanggalan dan kemudian dianggap final. Idealnya, kajian pertanggalan absolut dilakukan terhadap beberapa sampel dan akan lebih baik jika analisis dilakukan dengan radiokarbon modern. Setelah itu, seluruh hasilnya dikaji lagi dengan metode Bayesian untuk mendapatkan durasi aktivitas yang meyakinkan yang pernah terjadi di situs. Terakhir, kritisi kembali cara mendapatkan pertanggalan relatif.
\end{abstract}

Kata kunci: pertanggalan absolut, pertanggalan relatif, perkerangkaan sejarah, situs Patih Muhur, Kalimantan Selatan

\begin{abstract}
Sometimes the results of absolute dating analysis, does not fully resolve issue of the site chronology. Actually, some absolute dating results cause new problems, for example Patih Muhur site. Therefore, this study is intended to contribute ideas regarding the placement of Patih Muhur site within the framework of the historical kingdoms in South Kalimantan. The method used is descriptive-analytic. Applications are done by describing the stages of sampling, analyzing, and comparing the results of absolute and relative dating. The result is the discrepancy between absolute and relative dating which means that the validity of the dating result is not enough only in once dating (one sample), and then considered final. Ideally, absolute dating studies are conducted on several samples, and it is better by modern radiocarbon. After that, all the results are studied again with the Bayesian method to obtain conclusive duration of activity that had occurred on the site. Finally, the ways to get relative datingg need to be criticized.
\end{abstract}

Keywords: absolute radiocarbon dating, relative dating, historical timeline, Patih Muhur site, South Kalimantan

\section{PENDAHULUAN}

Pertanggalan adalah hal penting yang perlu diketahui terkait dengan temuan arkeologi dan atau cerita sejarah. Hanya saja dalam kenyataannya, pertanggalan itu bukanlah sesuatu yang sederhana untuk bisa diungkap. Maksudnya, bukan merupakan pekerjaan yang sederhana untuk mengungkap usia/pertanggalan situs dalam pernyataan yang tepat dan tidak terbantahkan. Dalam hal ini yang dimaksud tepat dan tidak terbantahkan adalah diperolehnya angka tahun yang tepat dan tidak mudah dicari celah untuk dimentahkan oleh pihak yang tidak menyepakatinya.

Kenyataan yang ada seperti apa? Biasanya, para arkeolog memperoleh pengetahuan mengenai umur suatu situs dengan pertanggalan relatif dan absolut. Pertanggalan relatif diperoleh dengan mendasarkan pada kesetaraan teknologi yang dikenal dan juga dengan tingkatan budaya yang berhasil dilampaui yang diketahui dari 
peralatan yang dipergunakan. Misalnya pada suatu situs diperoleh temuan fragmen tembikar, para arkeolog menghubungkannya sebagai situs yang berasal dari masa neolitik (Forestier 1998: 70). Demikian juga ketika ditemukan peralatan dari metal, maka umur situs dipastikan berasal dari masa logam, atau lebih luasnya disebut masa perundagian (Poesponegoro 2008: 289).

Di Indonesia, umumnya pertanggalan mutlak diperoleh dari prasasti yang bertuliskan angka tahun atau dengan analisis yang disebut pertanggalan radiokarbon (radiocarbon dating), ${ }^{14} \mathrm{C}$ atau pertanggalan absolut. Walaupun ada juga pertanggalan yang dapat diketahui dengan metode thermoluminescence, potassium argon dating dan pertanggalan jejak belah (fission track dating) (Faisal 2009: 71). Hanya saja arkeolog Indonesia biasanya memanfaatkan metode radiocarbon dating. Seperti apa hasil pertanggalan dengan metode radiokarbon? Contoh hasil pertanggalan radiokarbon adalah $648 \pm 110 \mathrm{BP}$ (1950). Melihat hasil yang demikian ini, maka rentang waktu masih sangat panjang, yaitu 12001420 Masehi.

Dampak dari rentang waktu yang panjang, kadang-kadang akan melampaui rentang waktu berdasarkan pengetahuan cerita sejarah, misalnya pada kasus umur situs Candi Agung. Berdasarkan asumsi yang berkembang, Candi Agung sering dikaitkan dengan pengaruh Majapahit. Berdasarkan material bangunan candinya yang berupa bata, menunjukkan pengaruh Majapahit pada sekitar abad ke-14 (Kusmartono dan Widianto 1997/1998: 20). Dugaan tersebut didasarkan pada material candinya. Sementara itu, Bambang Sulistyanto (2000: 40-41) mengajukan argumen lain yang didasarkan pada Hikayat Banjar, tradisi yang berupa nyanyian wadian pada masyarakat suku Dayak, dan juga Negarakertagama, terutama pada pupuh 15. Datadata itu menunjukkan kehadiran Majapahit di Kalimantan Selatan pada abad ke-14 Masehi.

Akan tetapi, ketika melihat umur relatif jenis bahan bangunan yang diduga pengaruh Majapahit pada abad 14, data Hikayat Banjar, Negarakertagama, dan tradisi pada suku Dayak yang kemudian dibandingkan dengan hasil pertanggalan absolut dengan metode radiocarbon dating, terdapat ketidaksinkronan. Candi Agung berdasarkan analisis radiocarbon dating menunjukkan usia pada abad ke-8 Masehi. Ada perbedaan sekitar 6 abad dengan dugaan usia relatifnya. Hal yang berbeda terjadi dalam hal penentuan umur situs Candi Laras (Sulistyanto 2000: 37-38), dengan mendasarkan pada hasil analisis radiocarbon dating, menunjukkan usia candi berasal dari abad ke-14 Masehi. Melihat hasil yang demikian ini, maka terdapat kesejajaran hasil analisis Candi Laras yang didasarkan pada usia relatifnya. Masalah ternyata tidak selesai sampai di situ. Dalam rangkaian penelitian di situs Candi Laras juga berhasil ditemukan potongan prasasti yang bertuliskan jaya siddha. Banyak prasasti yang menunjukkan bacaan demikian dan umumnya kata lengkapnya berbunyi jaya siddhayatra. Prasasti dari Sriwijaya yang memuat kata tersebut antara lain adalah prasasti Telaga Batu dan Bukit Siguntang, di Palembang. Makna kata tersebut adalah perjalanan ziarah untuk memperoleh berkah. Tulisan-tulisan yang berbunyi demikian banyak ditemukan pada prasasti yang berasal dari Kerajaan Sriwijaya pada abad ke-7-9 Masehi.

Mengapa kadang terjadi perolehan hasil pertanggalan absolut yang tidak sinkron dengan data material yang sebenarnya juga sulit terbantahkan kebenarannya, misalnya, arsitektur di Kalimantan Selatan sebelum terdapat candi, yang dikenal adalah berbahan kayu. Di sisi lain, candi berbahan bata juga baru dikenal di Jawa yang diduga memberi pengaruh ke Kalimantan Selatan, mulai dipergunakan pada abad ke-14 Masehi. Terkait dengan adanya contoh hasil pertanggalan yang tidak sinkron (situs Candi Agung dan Candi Laras), padahal hasil pertanggalannya diharapkan dapat menjembatani ketidaksinkronan pertanggalan absolut dan relatif, maka tema yang sama dan kaitannya dengan hasil pertanggalan absolut serta informasi Hikayat Banjar tentang situs Patih Muhur di Kabupaten Barito Kuala, dianggap penting untuk dibahas.

Pertanggalan adalah hal penting yang harus diketahui untuk dapat menempatkan suatu situs ke dalam perkerangkaan cerita sejarah situs yang bersangkutan dalam kaitannya dengan perjalanan sejarah Indonesia. Namun demikian, data yang 
ada kadang-kadang menunjukkan dualisme pertanggalan yang bertolak belakang, atau yang satu mengkounter data yang lain, seperti yang terlihat pada kasus di atas. Oleh karena itu, permasalahan yang perlu dibahas dalam tulisan ini adalah apa yang perlu dilakukan jika menemui ketidaksinkronan? Tulisan ini membahas kasus pertanggalan absolut di situs Patih Muhur, Kalimantan Selatan dan permasalahannya ketika akan ditempatkan dalam kerangka sejarah kerajaan-kerajaan di Kalimantan Selatan, yang pertanggalan relatifnya mempunyai rentang yang lebih sempit.

Berkaitan dengan bahasan yang dilakukan, tulisan ini dimaksudkan untuk memberikan sumbangan pemikiran untuk penyelesaian permasalahan yang berkaitan dengan penempatan situs Patih Muhur dalam kerangka sejarah kerajaan-kerajaan di Kalimantan Selatan. Upaya ini dilakukan sebagai bentuk sumbangan pemikiran yang mudah-mudahan bisa diterapkan, tidak hanya untuk situs Patih Muhur, tetapi juga dapat diterapkan pada situs lain dengan permasalahan yang mirip.

Harapannya, hasil pertanggalan absolut tidak menimbulkan permasalahan baru pada suatu situs. Maksudnya, dengan diketahuinya pertanggalan absolut, diharapkan umur situs tidak menjadi polemik karena telah dapat dipastikan dan tidak menimbulkan keraguan lagi. Lebih dari itu, hasil analisis umur absolut diharapkan selaras dengan posisi yang semestinya dalam kerangka sejarah suatu wilayah. Namun demikian, tidak jarang harapan itu jauh panggang dari api. Contohnya seperti terlihat pada hasil analisis umur absolut dan relatif pada situs Candi Agung dan Candi Laras. Hasil pertanggalan absolut pada situs Patih Muhur, Kabupaten Barito Kuala, Kalimantan Selatan pun harus dicermati. Melihat yang demikian ini tampaknya yang perlu dikaji adalah bagaimana pengambilan sampel itu dilakukan, sampel apa yang diambil dari situssitus yang bersangkutan, dan bagaimana penanganannya baik pada saat pengambilan maupun perlakuannya di laboratorium.

Pengamatan pada tahapan ini penting diketahui sebagai upaya untuk memastikan bahwa cara dan perlakuan untuk memperoleh hasil yang meyakinkan tidak diragukan lagi. Wisjachudin Faisal dkk. (1995: 240-242) yang mengkaji pertanggalan zaman kuarter dengan menggunakan analisis radiocarbon mengemukakan bahwa pengambilan sampel untuk tujuan itu dilakukan dengan perlakuan membungkus sampel dengan alumunium foil. Cara ini dimaksudkan untuk menghindarkan kemungkinan terjadinya kontaminasi data dengan sentuhan tangan yang dikhawatirkan terdapat bahan kimia lain yang bisa menjadikan biasnya hasil analisis radiocarbon.

Dalam kesempatan yang berbeda, peneliti ini juga melakukan kajian pertanggalan absolut terhadap situs Candi Jabung di Jawa Timur. Data yang digunakan adalah arang yang diperoleh dari penggalian yang berjarak puluhan meter dari objek candi. Dilakukannya pengambilan sampel yang tidak berkonteks langsung dengan candi karena memang saat penelitian tidak ditemukan data berkonteks dengan candi yang dapat dipakai untuk analisis radiocarbon. Oleh karena itu, data arang yang berjarak puluhan meter dari candi itulah yang dijadikan bahan kajian. Sementara itu, perlakuan terhadap sampel ketika akan dianalisis disebutkan bahwa arang dicuci dengan air, dibersihkan dari kotoran (tanah), dan dibilas dengan aquades. Setelah itu dilanjutkan dengan pencucian dengan metode asam-basa-asam,

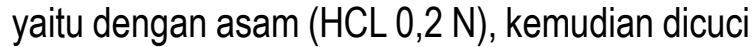
dengan aquades, diikuti dengan basa $(\mathrm{NaOH} 0,2$ $\mathrm{N})$ dan dicuci lagi dengan aquades dan diakhiri dengan pencucian menggunakan asam. Hasilnya, memang sinkron antara pertanggalan absolut dengan relatif (Faisal dkk. 2000:188-189 dan 191).

Melihat hasil yang sinkron antara pertanggalan relatif dan absolut, maka tidak ada masalah. Langkah berikutnya dalam memanfaatkan kedua hasil pertanggalan situs, cukup dengan menempatkan hasil pertanggalan itu saja, sudah bisa menjadi satu kesatuan paparan yang saling mendukung. Ketika ketidaksinkronan terjadi, maka penjelasan-penjelasan atas dua pertanggalan tersebut harus dilakukan untuk kemudian hal itu digunakan sebagai alasan pembenar ketika pilihan pertanggalan itu dilakukan. Kasus pertanggalan absolut dan pertanggalan berdasarkan cerita hikayat terkait 
situs Patih Muhur, mungkin juga perlu penjelasan itu. Jika kita perhatikan maka ada sedikit ketidaksinkronan antara informasi dari pertanggalan relatif yang berdasarkan cerita hikayat yang diyakini masyarakat Kalimantan Selatan yang menyebut keberadaan Kerajaan Negara Daha pada kisaran tiga generasi sebelum berdirinya Kerajaan Banjar, yaitu tahun 1526.

Generasi pertama sebagai pendiri Kerajaan Negara Daha (pada saat yang sama juga mendirikan Bandar Muara Bahan) adalah Maharaja Sari Kaburungan. Setelah itu, pucuk pimpinan kerajaan diwariskan kepada anaknya, Maharaja Sukarama (Ras 1968: 39 dan 72). Pergantian kekuasaan tersebut berjalan mulus (wajar), sehingga diperkirakan usia pemerintahan mereka, masing-masing berkisar 40 tahun. Selanjutnya generasi ketiga adalah Pangeran Tumenggung, adik dari Pangeran Mangkubumi (anak tertua Maharaja Sukamara). la menggantikan Sukamara karena kakaknya telah meninggal dan wasiat dari Sukamara agar anak dari Pangeran Mangkubumi, yaitu Pangeran Samudra yang harus menjadi raja. Oleh karena Pangeran Samudra masih terlalu kecil, maka pemerintahan dijalankan oleh pamannya, yaitu Pangeran Tumenggung. Dengan demikian, kedua tokoh ini (Pangeran Tumenggung dan Pangeran Samudra) hidup dalam masa yang sama. Jika Pangeran Samudra mengungsi dan mengumpulkan kekuatan sekitar 10 hingga 20 tahun, baru kemudian menyerang pamannya untuk mendapatkan haknya atas Kerajaan Negara Daha, maka waktu berdirinya Kerajaan Negara Daha adalah sekitar 100 tahun sebelum berdirinya Kerajaan Banjar (tahun 1526). Oleh karena itu, Kerajaan Negara Daha dan pembangunan Bandar Muara Bahan diduga terjadi pada sekitar tahun 1426 Masehi.

Ketika hasil pertanggalan relatif dan absolut tidak melenceng jauh antara satu dengan yang lain, tidak terjadi masalah jika pertanggalan itu digunakan untuk dasar meletakkan suatu situs dalam kerangka sejarah di suatu wilayah tertentu. Namun akan terjadi sebaliknya, jika diperoleh hasil pertanggalan relatif dan absolut yang tidak sinkron satu dengan yang lain. Dalam kasus yang demikian ini, harus dilakukan evaluasi atas analisis yang dilakukan baik yang dari pertanggalan absolut maupun relatif.

Evaluasi hasil pertanggalan absolut barangkali dapat dilakukan pada tahapan pengambilan sampel, alasan pemilihan sampel, dan penanganan. Pengambilan sampel untuk analisis petanggalan absolut harus memenuhi syarat-syarat tertentu. Dalam analisis radiokarbon, G. W. Pearson (1986: 911) menyebutkan bahwa syarat mendasar dalam pengambilan sampel yang bisa dipertanggungjawabkan untuk bisa memberikan hasil analisis dengan presisi tinggi, yaitu dengan kondisi sampel harus asli dan tidak terkontaminasi. Syarat lain adalah ukurannya dalam kondisi yang standar dan stabil. Sebagai upaya untuk mendapatkan sampel yang tidak terkontaminasi, Wisjachudin Faisal dkk. (1995: 242) menggambarkan cara yang dilakukan dalam pengambilan sampel dengan segera membungkusnya dengan alumunium foil.

Mengenai alasan pengambilan sampel, pada kasus penelitian pertanggalan radiokarbon di Candi Jabung yang dilakukan Wisjachudin Faisal dkk. (2000: 189), didasarkan pada adanya sampel yang paling dekat dengan candi. Dalam penelitian yang dilakukan, temuan yang mungkin dimanfaatkan untuk kegiatan analisis radiokarbon, tidak ada sampel yang didapatkan secara langsung berkonteks dengan candi. Temuan yang berkonteks langsung dengan candi hanya berupa batu-batu, sedangkan temuan seperti arang, yang memungkinkan untuk dijadikan objek untuk analisis radiocarbon dating, diperoleh pada jarak puluhan meter dari candi. Oleh karena itu, temuan tersebutlah yang kemudian digunakan sebagai bahan penelitian dalam analisis umur absolut dengan metode radiokarbon.

\section{METODE}

Kajian penulisan ini dilakukan dengan metode deskriptif-analitik. Metode deskriptif digunakan untuk mengumpulkan informasi mengenai status suatu gejala yang ada, yaitu keadaan menurut apa adanya yang terjadi di lapangan. Metode analitis digunakan untuk melacak lebih jauh mengenai hal-hal yang 
melatarbelakangi terjadinya suatu hal (Huda 2008: 11). Kajian dengan metode deskriptif-analitik dimaksudkan untuk mengetahui dan memahami fenomena untuk dijadikan bekal dalam menganalisis sehingga permasalahan yang melingkupinya akan teratasi.

Langkah yang dilakukan adalah melihat hasil analisis umur absolut pada situs Patih Muhur. Hasil itu dicoba diperhatikan tahapan pengambilan sampelnya. Apa yang bisa diketahui dicoba diulas untuk mendapatkan pengetahuan cara penanganan dan sekaligus bisa diukur tingkat kesahihan prosedur yang dilakukan. Selanjutnya, hasil pertanggalan absolut dicoba dipertemukan dengan hasil pertanggalan relatif yang ada dan berkaitan dengan situs yang dimaksud (Patih Muhur). Tentu dalam hal ini juga akan diperhatikan alasan diperolehnya umur relatif tersebut dan akan dilakukan evaluasi untuk memastikan kesahihannya.

Upaya mempertemukan dua hasil pertanggalan tersebut akan menunjukkan dua kemungkinan, yaitu sinkron atau tidak sinkron (tidak saling mendukung kebenaran hasil pertanggalannya). Jika keduanya sinkron, tentu tidak menimbulkan masalah. Akan tetapi jika terdapat ketidaksinkronan, maka yang harus dilakukan adalah evaluasi, baik terhadap pertanggalan absolut maupun relatifnya. Hasil evaluasi itu berupa saran mengenai apa yang harus dilakukan agar dapat diperoleh pertanggalan yang meyakinkan dan keduanya saling mendukung.

\section{HASIL DAN PEMBAHASAN}

\section{Patih Muhur: Situs dan Pertanggalannya}

Lokasi dan Objek Temuan

Tulisan ini menggunakan data hasil penelitian lahan basah, terutama mengenai pertanggalan absolut di situs Patih Muhur, di Kabupaten Barito Kuala. Patih Muhur merupakan salah satu desa dari 15 desa di wilayah Kecamatan Anjir Muara, Kabupaten Barito Kuala, Kalimantan Selatan. Secara umum desa ini mempunyai ketinggian 1 s.d.2 meter dari permukaan air laut. Desa Patih Muhur wilayahnya relatif datar, sebagian besar

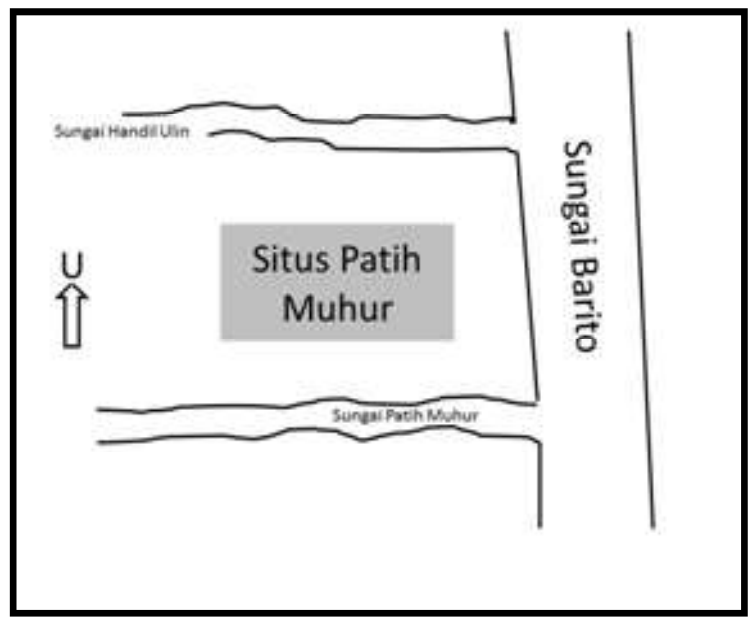

sumber: Wasita 2007: 43

Gambar 1. Sketsa keletakan situs Patih Muhur, di antara sungai-sungai.

berupa tanah rawa yang dimanfaatkan sebagai sawah pasang surut, seluas 2568 ha, dan sawah irigasi teknis, seluas 7568 ha. Beberapa sungai yang mengalir di wilayah ini, antara lain Sungai Barito, Sungai Patih Muhur, dan Handil Ulin. Sungai-sungai tersebut terutama sungai kecil (Patih Muhur dan Handil Ulin) merupakan sungaisungai yang mensuplai air ke Sungai Barito. Lebih dari itu, ketiga sungai tersebut merupakan areal yang membatasi keberadaan situs Patih Muhur (Wasita 2007: 17) (lihat gambar 1).

Temuan kayu ulin di situs Patih Muhur, sebagaimana digambarkan oleh Sunarningsih dkk. (2007: 4) merupakan jajaran ulin yang menancap di tanah (tonggak atau kayu utuh berbentuk gelondongan) dalam interval antara 12 meter membujur ke arah utara (sejajar Sungai Barito) dan interval 4 meter arah barat (tegak lurus dengan Sungai Barito). Jajaran tonggak ulin yang arahnya sejajar dengan Sungai Barito, ukuran panjangnya 9 meter. Sementara itu, tonggak berinterval 4 meter, terdapat 5 jajaran sehingga total berjarak 20 meter (arah tegak lurus dengan Sungai Barito). Dengan demikian jajaran-jajaran tonggak ulin itu membentuk denah empat persegi panjang, yaitu 9x20 meter (gambar 2).

Berdasarkan bekal pengetahuan yang telah dimiliki, pekerjaan yang kemudian dilakukan adalah survei untuk mengetahui lebih jauh tentang temuan tonggak ulin di luar jajaran yang membentuk formasi persegi panjang ukuran 9x20 


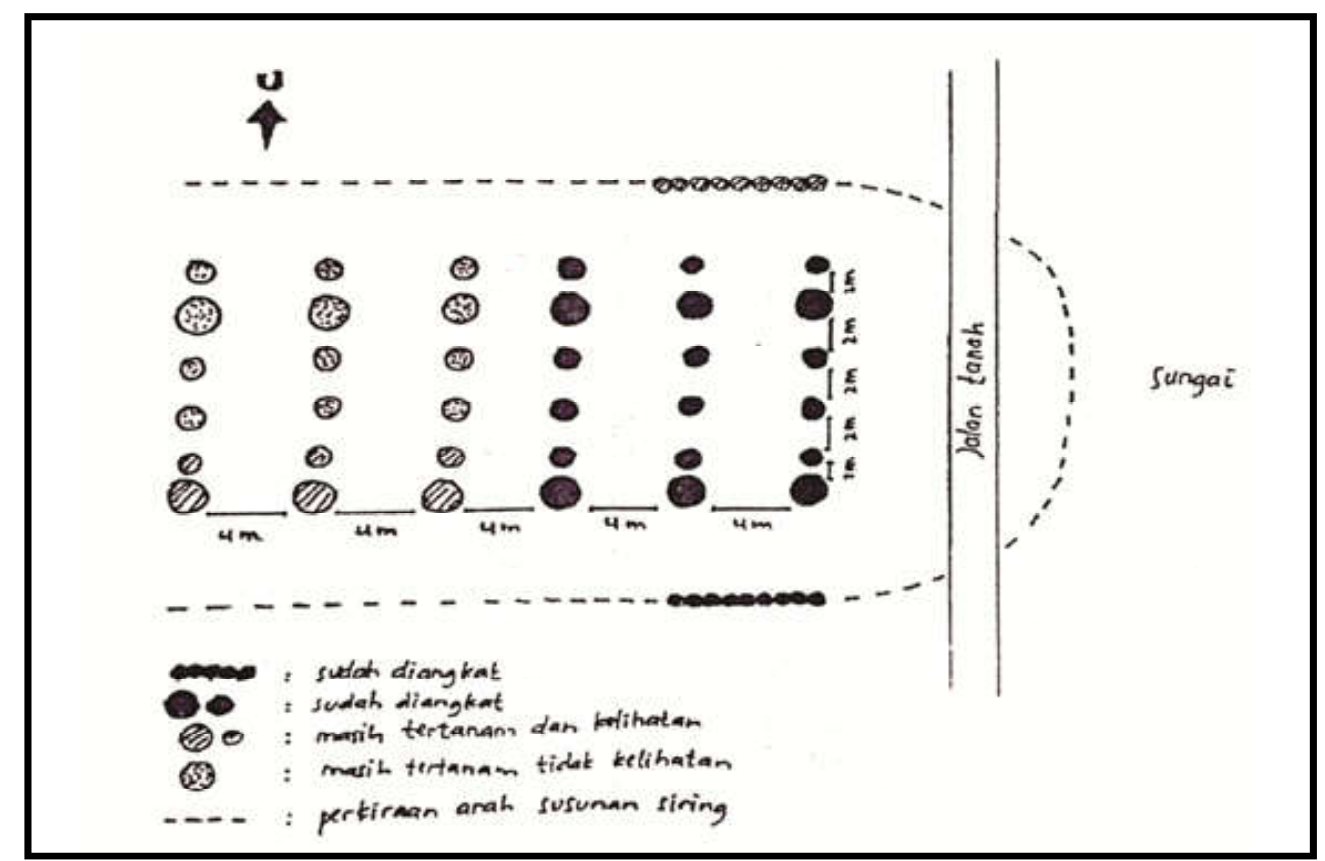

sumber: Sunarningsih dkk. 2007: 43

Gambar 2. Sketsa tonggak di situs Patih Muhur.

meter. Sebagian anggota tim penelitian yang tergabung dalam kelompok survei, ada yang memfokuskan penelusuran keberadaan jajaran tonggak ulin yang membujur ke arah 260-an derajat. Kelompok yang tergabung dalam survei ini ada empat orang dengan titik awal survei dari pekarangan tempat keberadaan temuan tonggak ulin dalam empat jajaran $(9 \times 20)$ meter.

Berdasarkan pengetahuan tersebut, survei yang dilakukan tim penelitian berhasil mengetahui bahwa temuan tonggak kayu ulin selain pada pekarangan yang berjajar rapi (9x20) meter, juga ditemukan pada lahan di sebelah selatannya (menjauhi Sungai Barito). Namun demikian, temuan tonggak kayu ulin tidak selalu ada pada interval empat meter. Hanya saja memang temuan ulin yang ada (berhasil ditemukan) jika diplotkan dalam interval 4 meter akan menempati posisinya atau bergeser beberapa centimeter. Temuan tonggak ulin yang demikian ini masih ditemukan hingga jarak 400 meter dari jarak terluar (9x20) meter. Setelah jarak 400 meter tersebut terdapat bukit yang tidak disurvei, tetapi setelah bukit itu dan masih dalam arah sekitar 260-an derajat kembali ditemukan tonggak ulin. Jarak temuan itu dari titik temuan jajaran ulin di bagian tepi sungai berada pada jarak 700 meter (Wasita 2007: 1823).

Lebih jauh mengenai tonggak-tonggak kayu ulin dapat dilihat pada sebagian tonggak yang telah dicabut. Bentuk tonggak (kayu utuh berbentuk gelondongan) itu lancip (seperti pensil yang diraut) (gambar 3 ). Ujung kayu gelondongan yang dibentuk lancip tersebut ketika diberdirikan berada pada posisi di bawah atau yang menancap ke tanah. Kayu-kayu gelondongan yang dibentuk tongkat yang menancap tersebut, umumnya berukuran panjang antara 5-6 meter. Dengan posisi menancap sedalam 4 hingga 5 meter, diyakini bahwa kayu-kayu tersebut memang sengaja diberdirikan. Terlebih lagi bahwa pada bagian yang mendekati permukaan tanah, tonggak kayu tersebut dibuat lubang persegi empat. Jadi sangat meyakinkan bahwa tonggak itu artifisial, bukan sebuah batang tanaman.

Hasil ekskavasi pada kotak gali yang permukaan tanahnya terdapat tonggak ulin, yang dilakukan pada kegiatan penelitian tahun 2007, menunjukkan bahwa sekitar satu meter di bawah permukaan tanah, tonggak kayu tersebut dibuat lubang segi empat yang dipakai untuk menaruh kayu sebagai sunduk. Di bawah kayu yang melintang sebagai sunduk terdapat kayu utuh 


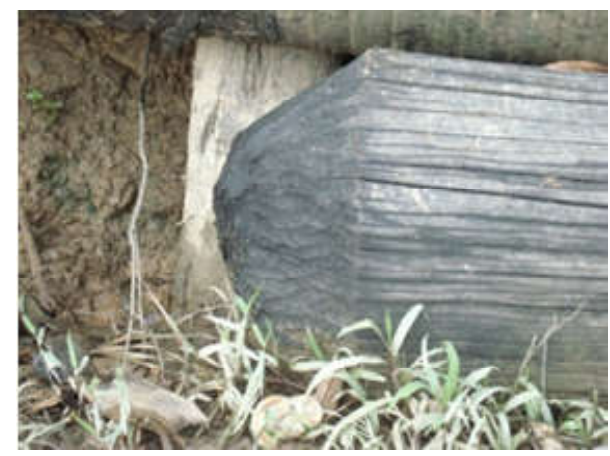

sumber: dok. Balar Banjarmasin

Gambar 3. Tiang kayu utuh yang dibentuk lancip untuk bagian yang menancap di tanah.

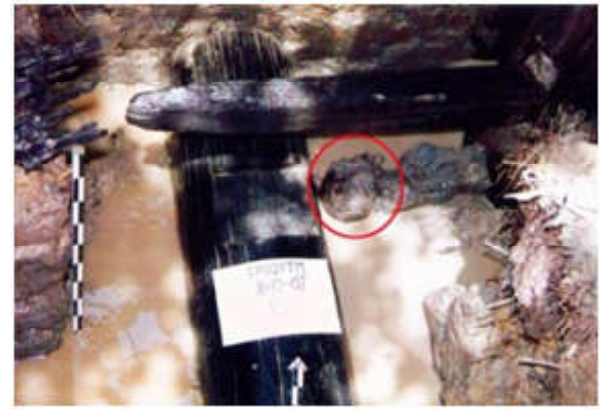

sumber: dok. Balar Banjarmasin

Gambar 4. Detail kayu galam (lingkaran merah) sebagai penahan kalangagar tidak bergeser.

(gelondongan) sebagai kalang. Kalang ini berfungsi sebagai penahan tonggak agar tidak amblas atau melesak turun ke dalam tanah. Sebagai upaya agar kalang tidak lepas dari posisinya karena menahan beban dari atas, maka di samping kanan dan kiri kalang ditahan dengan kayu galam (gambar 4). Kayu galam inilah yang dalam penelitian tahun 2007 diambil sebagai sampel untuk analisis radiocarbon dating guna mengetahui umur situs (Wasita 2007: 30-31).

\section{Pertanggalan Situs dan Penjelasannya}

Dipilihnya kayu galam sebagai sampel untuk analisis radiokarbon, didasarkan pada alasan bahwa kayu galam tersebut berkonteks dengan tonggak dan kalang-sunduknya. Memperhatikan posisinya, keberadaan kayu galam dimaksudkan sebagai penahan kalang agar tidak terlepas dari posisinya sebagai penahan tonggak agar tidak melesak. Fungsi galam yang demikian ini menunjukkan bahwa keberadaannya sangat penting. Nilai penting keberadaan galam terletak pada fungsinya untuk mempertahankan posisi kalang sehingga secara keseluruhan kestabilan tonggak akan terjaga.

Oleh karena fungsinya yang demikian penting pada saat tonggak atau tiang ulin tersebut difungsikan, maka keberadaannya pasti bersamaan dengan saat tonggak tersebut ditancapkan atau saat tonggak berfungsi sebagai struktur suatu bangunan. Sementara itu, kalau memperhatikan keberadaan ulin dan galam dalam satu kesatuan fungsi, maka yang dapat dipastikan dari keduanya adalah pemasangan dan penggunaannya bersamaan. Hal yang mungkin membedakan adalah waktu pengadaannya.

Kayu ulin sebagai kayu besar dan bersifat tahan lama, memiliki kemungkinan pengadaan atau penyiapannya jauh sebelum dimanfaatkan sebagai tonggak suatu bangunan di pinggir Sungai Barito tersebut. Sebagai kayu yang dapat bertahan lama, sangat mungkin juga bahwa kayu tersebut pernah digunakan sebelumnya dan digunakan lagi pada saat pendirian tonggak yang sekarang ditemukan di situs Patih Muhur.

Sifat tersebut berbeda dengan kayu galam. Terlebih lagi secara teknis, galam sulit bertahan lama jika tidak dimanfaatkan. Maksudnya, kayu galam yang sudah ditebang tetapi kemudian tidak dipergunakan dan penyimpanannya di atas permukaan tanah, tidak akan memiliki daya tahan seperti kayu ulin. Akan tetapi, menjadi berbeda ketahanannya jika galam terendam dalam tanah yang berair. Terlebih lagi secara teknis, kayu galam banyak tumbuh di lahan rawa dan ukurannya yang tidak besar, maka sangat mungkin bahwa penggunaan kayu galam tidak berselang lama dari waktu penebangannya. Dengan alasan tersebut diduga kayu galam tersebut digunakan tidak lama setelah ditebang. Oleh karena itu pula, maka sampel untuk menganalisis umur dengan radiokarbon digunakan atau dipilih dari bahan kayu galam.

Alasan itu diperkuat lagi dengan teori bahwa analisis umur dengan metode radiokarbon diperoleh dari penghitungan pelepasan/ peluruhan karbon (Chichagova dan Cherkinsky 1993: 353) setelah suatu makhluk mengalami 
kematian atau saat ditebang jika sampel berasal dari bagian pohon. Oleh karena teori penghitungan umur absolut yang demikian dan alasan teknis terkait dengan penebangan atau penyiapan kayu, maka pilihan sampel untuk analisis radiokarbon dari bahan kayu galam adalah alasan yang paling tepat.

Kayu galam yang dijadikan sampel analisis diambil dengan cara dipatahkan dari keberadaannya yang menancap dan menahan kalang. Pengambil sampel mengenakan kaos tangan dari bahan kain. Setelah dipatahkan, sampel itu kemudian langsung dibungkus dengan aluminium foil. Ketika masih di lapangan sampel yang telah terbungkus, diletakkan di lokasi yang terlindung dari sinar matahari secara langsung. Dua sampel yang diambil, yaitu kayu galam dan ulin (bagian dari sunduk). Akan tetapi yang dikirim ke laboratorium untuk dianalisis umur absolutnya hanya yang dari bahan kayu galam.

Berdasarkan hasil analisis di laboratorium terhadap sampel kayu galam tersebut diketahui umurnya adalah sebagai berikut, $640 \pm 110$ B.P. (1950). Hasil ini menunjukkan kisaran umur antara 1200-1420 Masehi. Perhitungan itu diperoleh dari rentang umur tertua dihitung dari $640+110=750$. Selanjutnya BP (before present-nya) diperoleh dengan perhitungan 1950-750 = 1200 Masehi. Umur termudanya diperoleh dari perhitungan 640$110=530$, sehinga diperoleh umur 1950-530 = 1420 Masehi. Dengan demikian umur situs Patih Muhur ada pada rentang antara 1200-1420 Masehi.

\section{Umur Situs Patih Muhur dan Keberadaannya Berdasarkan Rujukan Hikayat Banjar}

Permasalahan Hasil Radiokarbon Berkaitan dengan Posisi Patih Muhur dalam Rujukan Hikayat Banjar

Hasil pertanggalan radiokarbon terhadap temuan di situs Patih Muhur adalah antara 12001420. Padahal dalam Hikayat Banjar pada pupuh 2560 disebutkan bahwa Pangeran Samudra dalam perjalanannya ke arah hilir dalam rangka mengungsi, jika sudah sampai ke pelabuhan Muara Bahan, disarankan agar jangan berhenti. la disarankan untuk terus menjalankan perahunya menuju ke hilir dan berdiam di kampung orang Manjungaian, Sarapat, Balandean (Ras 1968: 382) dan Bandarmasih.

Uraian di atas menunjukkan bahwa hasil analisis radiokarbon berkaitan dengan umur atau waktu keberadaan situs Patih Muhur. Sementara itu, Hikayat Banjar menggambarkan sebuah perjalanan dengan beberapa lokasi. Memperhatikan sebutan bahwa jika perjalanan (dari Negara Daha, untuk mengungsi karena dikhawatirkan akan dibunuh pamannya) sudah sampai ke Bandar Muara Bahan agar terus menuju ke hilir, itu menandakan bahwa Pangeran Samudra memulai perjalanannya dari hulu, jika diplotkan dengan keberadaan Bandar Muara Bahan. Deskripsi perjalanan tersebut menunjukkan bahwa Bandar Muara Bahan posisinya juga lebih hulu jika dibandingkan dengan Manjungaian, Sarapat, Balandean dan Bandarmasih.

Tentang lokasi Negara Daha, di bagian awal tulisan J. J. Ras tidak menyebut dengan pasti. Dalam resensi II disebutkan bahwa kata Daha dipakai sebagai nama resmi kerajaan baru yang didirikan oleh Sakar Sungsang (Kaburungan). Petunjuk tentang keberadaan Negara Daha diperoleh pada saat cerita tentang Raden Samudra yang mendapat bantuan dari Demak hendak menyerang pamannya, Raden Tumenggung yang menguasai Kerajaan Negara Daha. Disebutkan bahwa Pangeran Samudra bergerak naik dari Bandarmasih (menuju ke hulu) hingga sampai di suatu wilayah yang disebut Sangianggantung. Dari sini baru kemudian naik (menuju ke hulu lagi) hingga tiba di Negara Daha. Setelah pertempuran dengan pamannya berhasil dimenangkan Pangeran Samudra, kesempatan masih diberikan kepada Pangeran Tumenggung untuk tetap dibiarkan hidup dan diijinkan tinggal di daerah Alai. Sementara itu, warga masyarakat Kerajaan Nagara Daha, semuanya dipindahkan ke Bandarmasih. Wilayah Nagara Daha tersebut sekarang dikenal dengan nama Nagara (Ras 1968: 47), yang posisinya di Kabupaten Hulu Sungai Selatan sekarang.

Dengan demikian, posisi Patih Muhur yang berada di sebelah hilir Kerajaan Negara Daha dan di sebelah hulu Sarapat dan Bandarmasih, 
memungkinkan jika temuan tonggak-tonggak kayu di Desa Patih Muhur adalah Bandar Muara Bahan pada masa kerajaan Negara Daha. Dugaan tersebut juga dikuatkan oleh posisi Sarapat yang juga ada di sebelah hilir temuan tonggak di Patih Muhur. Data yang agak kurang mendukung adalah keberadaan kampung Balandean. Saat ini masyarakat masih mengenal nama kampung itu, tetapi posisinya di seberang Desa Patih Muhur dan masih di tepi Sungai Barito juga. Padahal, menurut deskripsi perjalanan Pangeran Samudra, jika sudah sampai di Bandar Muara Bahan, diminta untuk melanjutkan perjalanan ke hilir menuju kampung Balandean, Sarapat, Manjungain, dan Bandarmasih. Akan tetapi, Balandean yang sekarang kita kenal tidak di hilirnya situs Patih Muhur, yang diduga sebagai Bandar Muara Bahan, tetapi di seberangnya. Posisi itu tidak seperti yang digambarkan oleh sumber Hikayat Banjar yang mendeskripsikan perjalanan Pangeran Samudra. Barangkali yang tidak bisa diplotkan dalam peta adalah nama Manjungaian.

Posisi Patih Muhur dalam Sejarah Kerajaankerajaan di Kalimantan Selatan

Dalam tulisan J.J. Ras (1968: 55-56) yang mengambil sumber dari Hikajat Banjar resensi I dan II, diketahui bahwa ada tiga nama kerajaan yang sama yang disebut dua resensi itu, yaitu Kerajaan Negara Dipa, Negara Daha, dan Banjar. Perbedaannya, resensi II tidak menyebut kerajaan Kayu Tangi dan Kerajaan Kota Waringin di Kalimantan Tengah. Namun demikian, dua kerajaan itu tidak terlalu terkait dengan upaya penempatan lokasi situs Patih Muhur, karena dua kerajaan yang tidak disebut oleh salah satu resensi itu tidak lagi berkonteks dengan keberadaan situs Patih Muhur yang diduga sebagai bekas Bandar Muara Bahan.

Mengenai letak Kerajaan Negara Dipa dan Daha, terdapat perbedaan antara sumber resensi I dan II. Resensi I menyebutkan bahwa Ampu Jatmika datang dan kemudian berdiam di Negara Dipa. Sementara itu, resensi II menyebutkan bahwa tempat pertama sebagai lokasi pemukiman mereka adalah Candi Laras, baru kemudian pindah ke Candi Agung di Amuntai. Resensi I menyebutkan bahwa ketika kerajaan masih bernama Negara Dipa, pelabuhan yang dimiliki bernama Muara Rampiau. Selanjutnya pada masa pemerintahan Sari Kaburungan, dibentuklah Kerajaan Negara Daha dengan pelabuhan di Muara Bahan. Akan tetapi pada saat berfungsinya kerajaan baru, kerajaan lama juga masih eksis, misalnya kerajaan lama masih menjadi tempat kediaman Putri Kalungsu dan Muara Rampiau kadang-kadang masih didatangi pedagang (Ras 1968: 57 dan 370). Dengan demikian pada masa Maharaja Sari Kaburungan, Kerajaan Negara Dipa dan Daha masih ada dan pelabuhan juga masih difungsikan dua-duanya.

Namun, ketika mencoba memperhatikan angka tahun yang berkaitan dengan masa berlangsungnya pemerintahan Kerajaan Negara Dipa dan Daha pada hikayat tersebut, tidak berhasil ditemukan. Jika memperhatikan tokohtokoh yang berhubungan dan yang disebut antara lain adalah Gadjah Mada dan Pikatan, mereka hidup pada pertengahan abad ke-14 Masehi. Pada abad-abad tersebut, di Majapahit memang banyak didirikan candi-candi dengan bahan bata. Oleh karena itu, jika memperhatikan jenis bangunan yang dikenal di Kalimantan Selatan, yang berasal dari sebelum abad ke-14 Masehi, umumnya menggunakan bahan kayu. Tidak atau belum pernah ditemukan bahan batu-bata yang merupakan arsitektur lokal Kalimantan Selatan. Ini berarti menguatkan dugaan bahwa keberadaan arsitektur berbahan bata merupakan pengaruh luar (Jawa), pada abad ke-14 Masehi atau sesudahnya.

Temuan periode tersebut menguatkan dugaan akan keberadaan bangunan berbahan bata di Kalimantan Selatan berasal dari abad ke14 Masehi. Namun temuan ini jika disinkronkan dengan hasil pertanggalan absolut pada situs Patih Muhur, akan mengalami kekurangtepatan waktu. Maksudnya, umur absolut hasil analisis radiokarbon menunjukkan rentang waktu antara 1200-1420 Masehi. Angka tahun tua (1200 Masehi) tidak tepat sebagai tahun masuknya pengaruh Majapahit dengan arsitektur berbahan bata.

Memperhatikan kenyataan yang demikian, makna apa yang ada di balik data pertanggalan tersebut? Ternyata sebuah upaya untuk mendapatkan pertanggalan absolut justru 
menjadikan ketidaksinkronan yang membuka perdebatan. Hal ini dapat membuka wawasan kita bahwa penggunaan analisis radiokarbon untuk periode yang tidak terlalu tua, mungkin tidak terlalu tepat. Atau barangkali harus ada upaya tambahan lagi sehingga hasil tidak hanya berhenti sampai di situ saja. Inilah yang barangkali perlu mendapatkan perhatian kita!

Solusi Analisis Pertanggalan Absolut dan Penggunaannya

Uraian di atas menunjukkan bahwa permasalahan akan muncul ketika terjadi ketidaksinkronan hasil pertanggalan absolut dan relatif, sehingga penempatan suatu situs dalam kerangka sejarah di suatu daerah sulit dilakukan. Hasil pertanggalan absolut situs Patih Muhur, data untuk analisis radiocarbon dating-nya diambil dengan cara dipatahkan dengan tangan langsung karena kondisi galam sudah agak rapuh. Pengambil sampel kayu tersebut mengenakan kaos tangan bahan kain. Begitu berhasil diambil, potongan galam segera dibungkus dengan alumunium foil. Setelah pengambilan sampel dan kemudian tim penelitian melanjutkan pekerjaannya, sampel kayu galam yang telah terbungkus diletakkan di tempat yang tidak terkena sinar matahari secara langsung.

Sementara itu, penanganan di laboratorium tidak diketahui karena tidak ada informasi mengenai hal itu dalam laporan hasil pertanggalannya. Akan tetapi saya yakin sudah ada standar perlakuan untuk pekerjaan tersebut. Tampaknya karena alasan telah adanya prosedur itulah, maka C.E. Buck dkk. (1994: 233) dalam upaya mendapatkan hasil mengenai durasi aktivitas yang dilakukan di suatu situs, dicari dengan cara analisis data-data yang ada. Analisis tersebut menggunakan metode Bayesian.

Konsep analisis Bayesian dilakukan dengan menggali dua sumber data (informasi) tentang parameter suatu model statistik. Sumber informasi pertama berasal dari sampel dan akan disebut informasi sampel (sample information), dalam hal ini adalah sampel pertanggalan absolut. Sumber informasi kedua berasal dari opini dan akan disebut informasi prior (prior information), dalam hal ini adalah sumber pertanggalan relatif yang merupakan hasil pemikiran para peneliti. Gabungan dua buah sumber informasi ini akan membentuk informasi posterior (posterior information). Penggabungan kedua sumber informasi ini dicapai melalui teorema Bayes (Bayesitheorem) (Buck dkk. 1994: 238).

Lebih lanjut C.E. Buck dkk. mencontohkan penggunaan teori Bayesian berdasarkan data dari 13 hasil pertanggalan kayu untuk mengetahui durasi aktivitas situs Chancay. Berdasarkan data yang ada, diketahui bahwa data umur termuda, disebut adalah 480 sampai 400 BP atau 14701550 AD. Sementara itu, data paling tuanya adalah 1220 sampai 950 BP atau 730-1000 AD. Sementara itu, range atau rentang umurnya dibatasi oleh hasil penelitian sejarah, di mana durasi aktivitas situs tersebut dibatasi pada periode pra-Hispanic. Konsekuensi dari hasil penelitian sejarah tersebut menempatkan pada kisaran tidak lebih dari pertengahan abad ke-16 (Buck dkk. 1994: 234235).

Dalam hal ini terlihat bahwa ada perbedaan antara durasi aktivitas situs dan umur berdirinya suatu bangunan di suatu situs. Durasi aktivitas adalah lama kegiatan yang pernah berlangsung di suatu situs. Lama kegiatan tersebut menunjukkan sejak ada indikasi usia tertua hingga termuda pada suatu situs. Dengan demikian, bisa saja terjadi aktivitas yang pernah berlangsung dari sebelum pendirian bangunan (dalam konteks ini Pelabuhan Muara Bahan) hingga setelah akhir masa pemerintahan kerajaan yang membangun pelabuhan tersebut.

Oleh karena kondisi itu, maka jenis data yang kemudian dijadikan sebagai sampel analisis radiokarbon menempati peran yang sangat menentukan. Pada kasus situs Patih Muhur, apabila kayu ulin yang digunakan untuk sampel analisis radiokarbon, sangat mungkin akan memberikan hasil yang berupa umur yang lebih tua dari kayu galam, tetapi bisa juga tidak. Sementara itu, untuk mengetahui waktu pembangunan pelabuhan, tidak serta merta bahwa hasil analisis radiokarbon dari sampel kayu yang terkait dengan pelabuhan, langsung dapat menunjuk umur yang pasti tentang waktu berdirinya pelabuhan. Sebenarnya, dalam analisis itu, yang didapatkan hanya berupa rentang 
aktivitas yang pernah ada dan terkait dengan sampel yang dimaksud.

Oleh karena adanya kemungkinan demikian, maka jika ingin mengetahui rentang waktu durasi aktivitas situs dan penerapannya dalam kerangka sejarah kerajaan-kerajaan di Kalimantan Selatan, berdampingan dengan pertanggalan relatif, tampaknya upaya analisis pertanggalan mutlak tidak hanya cukup dalam sekali analisis. Analisis tampaknya perlu dilakukan dalam banyak sampel, seperti halnya di situs Chancay dengan 13 analisis.

Dalam analisis Bayesian, ternyata memerlukan banyak data, terutama data sampel. Tidak hanya satu sampel dan satu opini, seperti data yang ada di situs Patih Muhur sekarang. Mendasarkan pada pandangan itu, maka situs Patih Muhur masih perlu analisis pertanggalan mutlak yang lebih banyak lagi agar bisa dilakukan analisis Bayesian. Pola analisis Bayesian yang digambarkan oleh C.E. Buck dkk. (1994: 230) bahwa pendekatan itu berguna untuk mendapatkan kronologi pada sebuah kelompok temuan yang memiliki beberapa sampel pertanggalan radiokarbon. Selanjutnya data-data pertanggalan tersebut dianalisis dengan metode Bayesian untuk mendapatkan durasi aktivitas arkeologi di suatu situs. Pada akhirnya, yang diperoleh juga merupakan rentang waktu aktivitas di suatu situs. Kelebihannya, rentang waktu tersebut diperoleh dari perhitungan statistik yang berdasarkan dari banyak data, sehingga lebih komprehensif.

Sementara itu, untuk memperpendek hasil mengenai rentang usia situs, tampaknya pandangan mengenai penggunaan metode radiokarbon modern perlu dilakukan. Analisis radiokarbon modern menggunakan alat spektrometer massa berbasis siklotron. Analisis ini hanya memerlukan cuplikan yang relatif lebih kecil, dan hasilnya menunjukkan simpangan baku yang juga relatif lebih kecil. Atas dasar ini diduga dalam perkembangannya radiokarbon modern akan dapat memberikan sumbangan yang baik dalam analisis pertanggalan arkeologi (Faisal 2009: 71, 74, dan 78). Hasil analisis ini memberikan rentang umur yang lebih pendek daripada analisis radiokarbon. Namun demikian, sejak gagasan itu dilontarkan dan hingga saat ini, terutama di Balai Arkeologi Banjarmasin, belum memanfaatkan metode yang ditawarkan tersebut. Justru, para peneliti masih menggunakan pertanggalan radiokarbon.

\section{PENUTUP}

Uraian di atas menunjukkan bahwa analisis pertanggalan absolut tidak serta-merta menyelesaikan masalah pertanggalan situs dan penempatannya dalam perkerangkaan sejarah di wilayah yang bersangkutan. Tampaknya umur yang tidak terlalu tua justru bisa menghasilkan bias pertanggalan absolut dan relatif. Ada beberapa hal yang perlu diperhatikan untuk menggunakan analisis ini. Adanya peringatan untuk memperhatikan beberapa hal, dimaksudkan agar pekerjaan yang dilakukan berhasil mendapatkan pencapaian yang maksimal dan meyakinkan.

Hal-hal yang perlu diperhatikan dalam kaitannya dengan analisis pertanggalan absolut adalah pengambilan sampel, penanganannya di laboratorium, dan penggunaannya perlu memperhatikan hasil pertanggalan lain. Jika situs yang dikaji adalah situs sejarah, maka dapat dibandingkan hasil pertanggalannya dengan pertanggalan relatif atas dasar kajian para ahli. Lebih dari itu, untuk bisa diperoleh kekayaan data, alangkah baiknya jika analisis pertanggalan absolut tidak hanya dilakukan dengan satu sampel. Sebaiknya dilakukan dengan beberapa sampel yang beragam sebagai upaya untuk mengontrol hasilnya.

Upaya melakukan analisis pertanggalan absolut dengan beberapa sampel pada akhirnya juga dapat dimanfaatkan untuk melakukan kajian dengan metode Bayesian. Jadi dengan penelitian yang intensif dengan berbagai metode adalah sebuah langkah yang baik untuk dapat memberikan penjelasan suatu situs. Oleh karena itu, bukan suatu hal yang tabu jika situs Patih Muhur perlu dikaji lagi dan bahkan dianalisis pertanggalan absolutnya lagi yang semua itu ditujukan untuk dapat memberikan penjelasan situs dengan lebih komprehensif. 
Untuk bisa menggunakan metode Bayesian, analisis pertanggalan pada situs Patih Muhur masih harus lebih banyak lagi dilakukan. Jadi masih cukup terbuka untuk melakukan analisis pertanggalan di situs tersebut, sehingga akan dapat memberikan sumbangan yang berarti.

\section{DAFTAR PUSTAKA}

Buck, C.E., J.A. Christen, J.B. Kenworthy dan C.D. Litton. 1994. "Estimating The Duration Of Archaeological Activity Using 14C Determinations". Oxford Journal of Archaeology 13 (2): 229-240.

Chichagova, O.A. dan A.E. Cherkinsky. 1993. "Problems in Radiocarbon Dating of Soils". Radiocarbon 35 (3): 351-362.

Faisal, Wisjachudin, Agus Taftazani., F. Lahagu, Sumiyatno, Suhardi, Imam Prayogo, Djiono, dan Wartono Rahardjo. 1995. "Pengkajian Stratigrafi Cupljkan Batuan Dari Zaman Kuarter Menggunakan Pertanggalan Radiokarbon". HIm. 239244 dalam Prosiding Pertemuan dan Presentasi IImiah PPNY-BATAN, Yogyakarta 25-27 April.

Faisal, Wisjachudin, Rosyidin, Sumiyatno, Siswanto, dan Darwin A.Siregar. 2000. "Pertanggalan Radiokarbon Pada Situs Candi Jabung Salah Satu Candi di Jawa Timur. HIm. 187-192 dalam Prosiding Pertemuan dan Presentasi IImiah Penelitian Dasar Ilmu Pengetahuan dan Teknologi Nuklir P3TM-BATAN, Yogyakarta, 25 -26 Juli.

Faisal, Wisjachudin. 2009. "Peran Metode Pertanggalan Radiometris di Bidang Arkeologi dan Geologi". Jurnal Iptek Nuklir Ganendra 12 (2): 70-81.

Forestier, Hubert. 1998. Ribuan Gunung, Ribuan Alat Batu: Prasejarah Song Keplek, Gunung Sewu, Jawa Timur. Jakarta: Kepustakaan Populer Gramedia.

Huda, Sokhi. 2008. Tasawuf Kultural: Fenomena

Shalawat Wahidiyah. Yogyakarta: LKiS.
Pearson, G.W., J R Pilcher, M G L Baillie, D M Corbett, and F Qua. 1986. "High-Precision 14C Measurement of Irish Oaks to Show the Natural 14C Variations from AD 18405210 BC". Radiocarbon 28 (2B): 911-934. Kusmartono, Vida Pervaya Rusianti dan Harry Widianto. 1997/1998. "Ekskavasi Situs Candi Agung Kabupaten Hulu Sungai Utara, Kalimantan Selatan". Berita Penelitian Arkeologi No. 2. Banjarmasin: Balai Arkeologi Banjarmasin.

Poesponegoro, Marwati Djoened. 2008. Sejarah

Nasional Indonesia I. Jakarta: Balai Pustaka.

Ras, J.J. 1968. Hikajat Bandjar: A Study in Malay Historiography. The Hague: Martinus Nijhoff.

Sulistyanto, Bambang. 2000. "Umur Candi Laras Dalam Panggung Sejarah Indonesia Kuna". Berita Penelitian Arkeologi No. 7. Banjarbaru: Balai Arkeologi Banjarmasin. Sunarningsih, Wasita, Bambang Sakti Wiku Atmojo, dan Nugroho Nur Susanto. 2007. "Temuan tonggak kayu ulin di Desa Patih Muhur Lama, Kecamatan Anjir Muara, Kabupaten Barito Kuala, Povinsi Kalimantan Selatan". Laporan Peninjauan. Banjarbaru: Balai Arkeologi Banjarmasin.

Wasita. 2007. "Ekskavasi Permukiman Lahan Basah di Situs Gambut, Kabupaten Banjar dan Patih Muhur, Kabupaten Barito Kuala, Kalimantan Selatan". Laporan Penelitian Arkeologi. Banjarbaru: Balai Arkeologi Banjarmasin. 